\title{
Platelet Membrane Glycoprotein 1b Alpha Chain
}

National Cancer Institute

\section{Source}

National Cancer Institute. Platelet Membrane Glycoprotein 1b Alpha Chain. NCI

Thesaurus. Code C126548.

Platelet glycoprotein Ib alpha chain (652 aa, $72 \mathrm{kDa}$ ) is encoded by the human GP1BA gene. This protein plays a role in von Willebrand factor binding. 